\title{
Intrahepatic expression of pre-S1 and pre-S2 antigens in chronic hepatitis $B$ virus infection in relation to hepatitis $B$ virus replication and hepatitis delta virus superinfection
}

Liver Unit,

Chang Gung Memorial Hospital and Chang Gung Medical College, Taipie, Taiwan, Republic of China

CM Chu

Y F Liaw

Correspondence to

Chia-Ming Chu, MD, Liver Hospital, 199 Tung Hwa North Road, Taipei Taiwan, 10591, Republic of China.

Accepted for publication 21 April 1992
Unit, Chang Gung Memoria

\author{
C M Chu, Y F Liaw
}

\begin{abstract}
Hepatocyte expression of pre-S1 and pre-S2 in relation to hepatitis $B$ virus replication (hepatitis $B$ virus-DNA in serum and $\mathrm{HBCAg}$ in the liver), histological activity and hepatitis delta virus superinfection was studied by indirect immunofluorescence on frozen sections of liver specimens from 68 patients with chronic hepatitis B virus infection. All 44 patients with chronic type $B$ hepatitis had preS1 and pre-S2 display in the liver. The distribution of pre-S1 in the liver was membranous in one, mixed membranous and cytoplasmic in 12, and cytoplasmic in 31 . The distribution of pre-S2 was membranous in one, mixed membranous and cytoplasmic in 26, and cytoplasmic in 17. Membranous expression of preS1 was significantly more prevalent in patients with active hepatitis $B$ virus replication than in those without $(13 / 28 v 0 / 16, \mathrm{p}<0.001)$, regardless of the histological activity, as was membranous expression of pre-S2 (27/28 $v 0 / 16$, $\mathbf{p}<0.001$ ). In contrast, a significantly higher extent of cytoplasmic expression of pre-S1 and pre-S2 was noted in patients without active hepatitis B virus replication than in those with. Of 24 patients with chronic type $D$ hepatitis virus, eight had active hepatitis $B$ virus replication, and the other 16 did not. The distribution and quantitative expression of preS1 and pre-S2 in the liver in these patients also correlated significantly with the status of hepatitis B virus replication and, moreover, showed little or no difference from those without hepatitis delta virus infection. In conclusion, all patients with chronic type B hepatitis had synthesis and display of pre-S1 and pre-S2 in the liver. The distribution and quantitative expression of pre-S1 and pre-S2, however, were closely related to the status of hepatitis B virus replication, but not to the histological activity. Hepatocyte expression of
\end{abstract}

TABLE I Clinical and laboratory data of patients studied

\begin{tabular}{|c|c|c|c|c|c|}
\hline Category & $\begin{array}{l}\text { Cases } \\
(n)\end{array}$ & $\begin{array}{l}\text { Age } \\
(y r)\end{array}$ & $\begin{array}{l}\text { Sex } \\
(M: F)\end{array}$ & $\underset{(n<40)}{\operatorname{AST}(I U / l)^{\star}}$ & $\underset{(n<40)}{\operatorname{ALT}(I U / l)^{\star}}$ \\
\hline $\begin{array}{l}\text { Without HDV superinfection } \\
\text { HBeAg positive MHC or CPH } \\
\text { HBeAg positive CAH } \\
\text { Anti-HBe positive CAH } \\
\text { Anti-HBe positive MHC }\end{array}$ & $\begin{array}{r}8 \\
16 \\
10 \\
10\end{array}$ & $\begin{array}{l}25(6) \\
28(8) \\
33(3) \\
35(9)\end{array}$ & $\begin{array}{r}6: 2 \\
14: 2 \\
10: 0 \\
10: 0\end{array}$ & $\begin{array}{r}44(10) \\
100(46) \\
94(45) \\
28(10)\end{array}$ & $\begin{array}{r}50(10) \\
212(88) \\
196(92) \\
33(15)\end{array}$ \\
\hline $\begin{array}{l}\text { With HDV superinfection } \\
\text { HBeAg positive CAH } \\
\text { Anti-HBe positive CAH }\end{array}$ & $\begin{array}{l}12 \\
12\end{array}$ & $\begin{array}{l}29(6) \\
34(7)\end{array}$ & $\begin{array}{l}12: 0 \\
12: 0\end{array}$ & $\begin{array}{l}92(42) \\
98(50)\end{array}$ & $\begin{array}{l}191(80) \\
200(92)\end{array}$ \\
\hline
\end{tabular}

HDV: hepatitis delta virus; $\mathrm{HBeAg}$ : hepatitis e antigen; anti-HBe: antibody to $\mathrm{HBeAg}$; $\mathrm{MHC}$ minimal histologic change; $\mathrm{CPH}$ : chronic persistent hepatitis; $\mathrm{CAH}$ : chronic active hepatitis. ^Data are mean (ISD).
pre-S1 and pre-S2 in chronic type $D$ hepatitis also correlated significantly with status of hepatitis B virus replication, and was not modulated by concurrent hepatitis delta virus infection.

(Gut 1992; 33: 1544-1548)

The three envelope antigens of hepatitis B virus are now well characterised: the major protein (HBsAg) with 226 amino acids encoded by the $\mathrm{S}$ gene, the middle protein (pre-S2) containing $\mathrm{HBsAg}$ and additional 55 amino acids encoded by the pre-S2 region, and the large protein (pre$S 1$ ) encoded by entire $S$ open reading frame, including the pre-S1 region, pre-S2 region and $\mathrm{S}$ gene. ${ }^{12}$ Both pre-S1 and pre-S2 proteins are expressed on the surface of $\mathrm{HBsAg}$ particles and may be essential components of complete virions and $\mathrm{HBsAg}$ filaments. ${ }^{3+}$ It has also been postulated that the attachment of hepatitis $B$ virus to hepatocytes is mediated by a receptor like function of pre-S proteins. ${ }^{56}$ Pre-S1 and pre-S2 proteins are detectable in the serum of patients with acute and chronic hepatitis $B$ virus infection when there is high levels of viral replication, and the clearance of these antigens from serum usually correlates with the prognosis of hepatitis $B$ virus infection. ${ }^{\text {7-12 }}$

Monoclonal antibodies against pre-S proteins have recently become available for tissue staining. Intrahepatic expression of pre-S1 and preS2 proteins has been studied in patients with chronic hepatitis $B$ virus infection, but the results still remain controversial. ${ }^{12-20}$ Studies of the molecular biology of hepatitis B virus have shown that the expression of HBsAg and pre-S2 protein is controlled by the same transcriptional promoter, whereas the expression of pre-S1 protein may be regulated independently by a second, usually less active, promoter..$^{21} 22$ In addition, there is a complex interaction between $\mathrm{HBsAg} /$ pre-S2 and pre-S1 that can lead to the cosecretion or the inhibition of secretion of these antigens, depending on the relative concentrations of $\mathrm{HBsAg} / \mathrm{pre}-\mathrm{S} 2$ and pre-S1. ${ }^{23}{ }^{2+}$ It seems that, in evaluating the significance of pre-S protein display in liver in chronic hepatitis B virus infection, special emphasis should be made on their topographical (cytoplasmic or membranous) distribution as well as the quantitative expression, as suggested in the study of intrahepatic expression of $\mathrm{HBsAg}$ and $\mathrm{HBcAg}$ in chronic type B hepatitis. ${ }^{25}$ Furthermore, it has long been suggested that there is an inhibitory effect on hepatitis $B$ virus replication by hepatitis 
delta virus in chronic hepatitis $B$ virus infection, ${ }^{26}{ }^{27}$ but it remains unclear whether hepatitis delta virus might interfere with the expression of hepatitis $\mathrm{B}$ virus envelope antigens in the liver or not.

In the present study, intrahepatic expression of pre-S1 and pre-S2 antigens was studied in patients with chronic type $B$ hepatitis, and the results were correlated with the status of hepatitis B virus replication, histological activity, and hepatitis delta virus superinfection.

\section{Methods}

\section{PATIENTS}

The study consisted of 68 patients with chronic hepatitis B virus infection. All had been $\mathrm{HBsAg}$ positive for more than six months and had histologic features of chronic hepatitis. Forty four patients were chronic type $B$ hepatitis without hepatitis delta virus superinfection, and the remainder 24 patients were chronic $\mathrm{HBsAg}$ carriers with hepatitis delta virus superinfection. Of the latter, all were positive for antibody against hepatitis delta virus (anti-HDV) and had hepatitis delta virus antigen (HDAg) detectable in the liver. None admitted intravenous drug abuse, nor had received antiviral or immunosuppressive treatment. The histologic diagnosis of chronic hepatitis was made according to the standard criteria. ${ }^{28}$ The clinical and laboratory data of the patients studied are listed in Table I.

\section{LABORATORY METHODS}

Serum aspartate aminotransferase and alanine aminotransferase were measured by sequential multiple autoanalysers. $\mathrm{HBsAg}, \mathrm{HBeAg}$, anti$\mathrm{HBe}$ and anti-hepatitis delta virus were assayed using commercially available radioimmunoassay kits (Ausria-II, HBeAg,-RIA, and anti-delta, Abbott Laboratories, Chicago, Illinois, USA). Serum hepatitis B virus-DNA was assayed by spot hybridisation with ${ }^{32} \mathrm{P}$-labelled cloned hepatitis B virus-DNA, as reported previously. ${ }^{29}$ immunofluorescence staining of pre-S2 on frozen section of the liver from an $\mathrm{HBeAg}$ positive patient with chronic active hepatitis, showing diffuse distribution of pre$S 2$ on the plasma membrane and only focal distribution of pre-S2 in the cytoplasm.

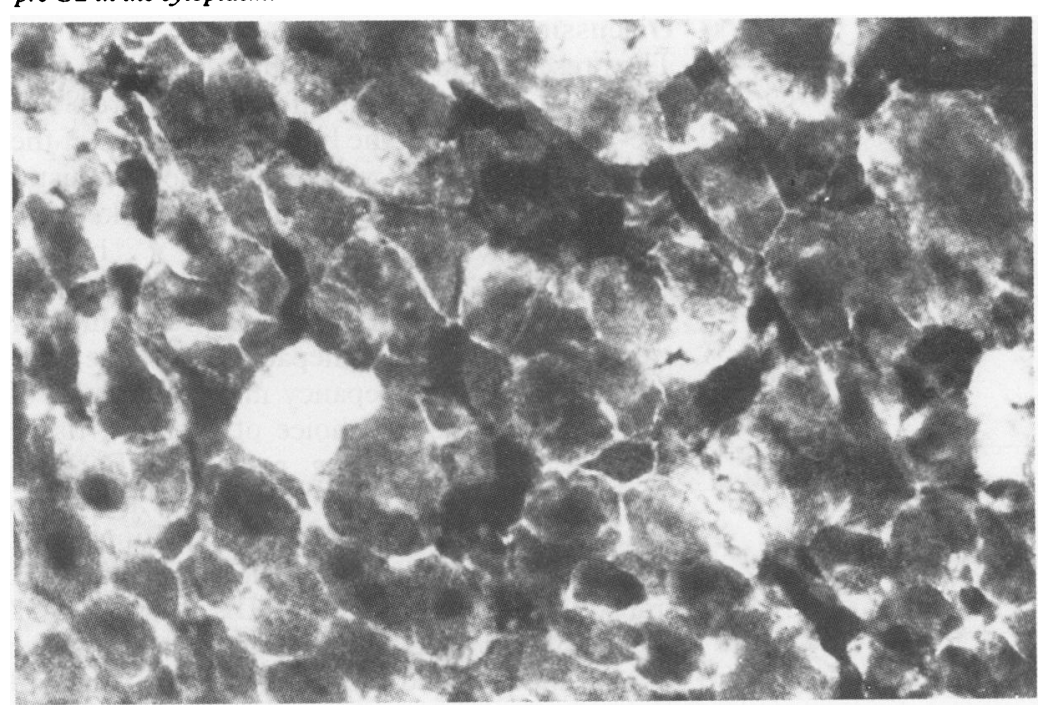

needle biopsy with a Menghini needle. Fragments of specimens were snap-frozen in liquid nitrogen cooled isopentane and stored at $-70^{\circ} \mathrm{C}$ until use. Samples of the same biopsy specimens were also fixed in $10 \%$ formaldehyde and embeded in paraffin wax for routine histologic diagnosis. Cryostat sections of $5 \mu \mathrm{m}$ were dried overnight at room temperature and fixed in carbon tetrachloride at $4^{\circ} \mathrm{C}$ for 10 minutes, followed by extensive washing with phosphate buffered saline ( $\mathrm{pH} \mathrm{7 \cdot 2)}$ before staining. HBsAg was detected by indirect immunofluorescence using mouse monoclonal antibody against the 'a' epitope of HBsAg (Chemicon, Temecula, CA, USA). HBcAg was detected by indirect immunofluorescence using rabbit anti-HBc (Dako Corporation, Santa Barbara, CA, USA), and HDAg was detected by direct immunofluorescence using fluorescein isothiocyanate (FITC) labelled anti-hepatitis delta virus, kindly supplied by Dr Rizzetto, as previously reported. ${ }^{30}$ Pre-S1 and pre-S2 were detected by indirect immunofluorescence using mouse monoclonal antibodies against pre-S1 and preS2, respectively, followed by FITC-conjugated rabbit anti-mouse immunoglobulin $\mathrm{G}$ (Jackson Immuno Research Laboratories, West Grove, Pennsylvania, USA). Monoclonal anti-pre-S1 and anti-pre-S2, which were produced by cell line T0606 and 5520, respectively, were obtained from Institute of Immunology, Tokyo, Japan. ${ }^{31}$ As a control, sections were incubated with phosphate buffered saline instead of the primary monoclonal antibodies in the first step. In addition, sections of liver tissues from patients without serological markers of hepatitis $B$ virus infection were stained using the identical techniques as negative controls. Only if the control preparations were negative was the staining considered positive. The expression of pre-S1 or pre-S2 in the liver was semiquantitatively scored according to the proportion of positive cells on a 0 to $4+$ scale corresponding to positivity in $0 \%$, $1-10 \%, 11-25 \%, 26-50 \%$, and $>50 \%$ of hepatocytes examined.

\section{STATISTICAL ANALYSIS}

The significance of difference between two proportions was assayed using $\chi^{2}$ test with Yates' correction. The difference in the number of hepatocytes positive for pre-S1 or pre-S2 between two groups of patients was compared using Wilcoxon's rank-sum test.

\section{Results}

All of the 68 patients, with or without hepatitis delta virus infection, had the three hepatitis B virus envelope proteins detectable in the liver, on the plasma membrane and/or in the cytoplasm. The expression of the hepatitis B virus envelope proteins on the plasma membrane was usually diffuse, while that in the cytoplasm was either focal or in cluster. Figures 1 and 2 illustrate the representative findings of the expression of pre$\mathrm{S} 2$ in the liver. The distribution and quantitative expression of pre-S2 were essentially the same as those of HBsAg. The expression of pre-S1 was solely membranous in one, mixed membranous 


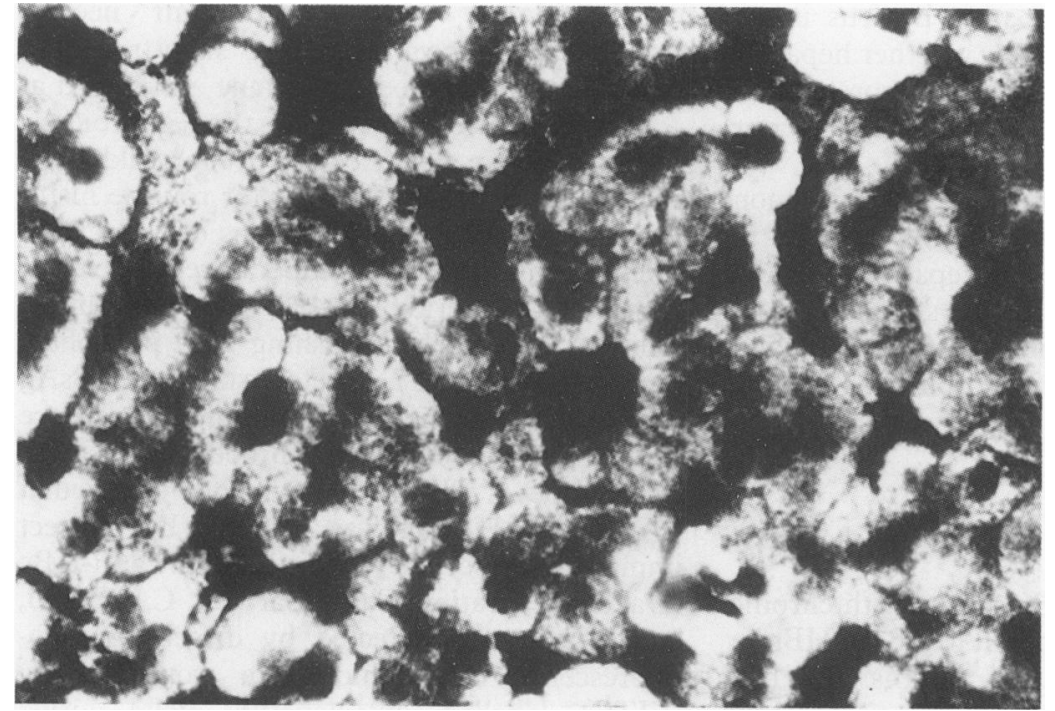

Figure 2: Indirect immunofluorescence staining of pre-S2 on frozen section of the liver from an anti-HBe-positive patient with minimal histological change, showing wide-spread expression of pre-S2 in the cytoplasm.

TABLE II Intrahepatic expression of pre-S1 and pre-S2 in chronic type B hepatitis

\begin{tabular}{|c|c|c|c|c|}
\hline \multirow[b]{2}{*}{ Category } & \multicolumn{2}{|l|}{ Pre-S2 } & \multicolumn{2}{|l|}{ Pre-S1 } \\
\hline & $\begin{array}{l}M / M+ \\
C / C\end{array}$ & $\begin{array}{l}\text { Cases with } \\
\text { membranous } \\
\text { pre-S2(\%) }\end{array}$ & $\begin{array}{l}M / M+ \\
C / C\end{array}$ & $\begin{array}{l}\text { Cases with } \\
\text { membranous } \\
\text { pre-S1 }(\%)\end{array}$ \\
\hline $\begin{array}{l}\text { With active HBV replication } \\
\text { HBeAg positive MHC or CPH }(n=8) \\
\text { HBeAg positive CAH }(n=16) \\
\text { Anti-HBe positive CAH }(n=4) \\
\text { Subtotal }(n=28)\end{array}$ & $\begin{array}{l}0 / 7 / 1 \\
1 / 15 / 0 \\
0 / 4 / 0 \\
1 / 26 / 1\end{array}$ & $\begin{array}{l}87 \cdot 5 \\
100 \\
100 \\
96 \cdot 4^{\star}\end{array}$ & $\begin{array}{l}0 / 4 / 4 \\
1 / 6 / 9 \\
0 / 2 / 2 \\
1 / 12 / 15\end{array}$ & $\begin{array}{l}50 \\
43 \cdot 8 \\
50 \\
46 \cdot 4 \dagger\end{array}$ \\
\hline $\begin{array}{l}\text { Without active HBV replication } \\
\text { Anti-HBe positive CAH }(n=6) \\
\text { Anti-HBe positive MHC }(n=10) \\
\text { Subtotal }(n=16)\end{array}$ & $\begin{array}{l}0 / 0 / 6 \\
0 / 0 / 10 \\
0 / 0 / 16\end{array}$ & $\begin{array}{l}0 \\
0 \\
0^{\star}\end{array}$ & $\begin{array}{l}0 / 0 / 6 \\
0 / 0 / 10 \\
0 / 0 / 16\end{array}$ & $\begin{array}{l}0 \\
0 \\
0+\end{array}$ \\
\hline
\end{tabular}

HBV: hepatitis B virus; $M$ : membranous; $C$ : cytoplasmic; $M+C$ : mixed membranous and cytoplasmic. For other abbreviations, see Table I

${ }^{\star} \mathrm{p}<0.001,+\mathrm{p}<0.01$ (by $\chi^{2}$ test with Yates' correction).

TABLE III Semiquantitative expression of pre-S1 and pre-S2 in hepatocyte cytoplasm in chronic type B hepatitis

\begin{tabular}{|c|c|c|c|c|c|c|c|c|c|c|}
\hline \multirow[b]{2}{*}{ Category } & \multicolumn{5}{|c|}{ Pre-S2 } & \multicolumn{5}{|c|}{ Pre-S1 } \\
\hline & 0 & $1+$ & $2+$ & $3+$ & $4+$ & 0 & $1+$ & $2+$ & $3+$ & $4+$ \\
\hline $\begin{array}{l}\text { With active HBV replication } \\
\text { HBeAg positive MHC or CPH }(n=8) \\
\text { HBeAg positive CAH }(n=16) \\
\text { Anti-HBe positive CAH }(n=4) \\
\text { Subtotal }(n=28)\end{array}$ & $\begin{array}{l}0 \\
1 \\
0 \\
1\end{array}$ & $\begin{array}{r}6 \\
10 \\
2 \\
18\end{array}$ & $\begin{array}{l}2 \\
4 \\
2 \\
8\end{array}$ & $\begin{array}{l}0 \\
1 \\
0 \\
1\end{array}$ & $\begin{array}{l}0 \\
0 \\
0 \\
0^{\star}\end{array}$ & $\begin{array}{l}0 \\
1 \\
0 \\
1\end{array}$ & $\begin{array}{r}6 \\
11 \\
1 \\
18\end{array}$ & $\begin{array}{l}1 \\
3 \\
3 \\
7\end{array}$ & $\begin{array}{l}1 \\
1 \\
0 \\
2\end{array}$ & $\begin{array}{l}0 \\
0 \\
0 \\
0+\end{array}$ \\
\hline $\begin{array}{l}\text { Without active HBV replication } \\
\text { Anti-HBe positive CAH }(n=6) \\
\text { Anti-HBe positive MHC }(n=10) \\
\text { Subtotal }(n=16)\end{array}$ & $\begin{array}{l}0 \\
0 \\
0\end{array}$ & $\begin{array}{l}0 \\
0 \\
0\end{array}$ & $\begin{array}{l}4 \\
4 \\
8\end{array}$ & $\begin{array}{l}2 \\
5 \\
7\end{array}$ & $\begin{array}{l}0 \\
1 \\
1^{\star}\end{array}$ & $\begin{array}{l}0 \\
0 \\
0\end{array}$ & $\begin{array}{l}0 \\
0 \\
0\end{array}$ & $\begin{array}{l}3 \\
3 \\
6\end{array}$ & $\begin{array}{l}2 \\
5 \\
7\end{array}$ & $\begin{array}{l}1 \\
2 \\
3 t\end{array}$ \\
\hline
\end{tabular}

For abbreviations, see Tables I and II. Scales of 0 to $4+$ corresponding to positivity in $0 \%, 1-10 \%$, $11-25 \%, 26-50 \%,>50 \%$ of total hepatocytes examined.

${ }^{\star} \mathrm{p}<0.001,+\mathrm{p}<0.001$, and no significant difference $(\mathrm{p}>0.05)$ between pre-S2 and pre-S1 expression in each subgroup (by Wilcoxon's rank-sum test).

TABLE IV Intrahepatic expression of pre-S1 and pre-S2 in chronic type D hepatitis

\begin{tabular}{|c|c|c|c|c|}
\hline \multirow[b]{2}{*}{ Category } & \multicolumn{2}{|l|}{ Pre-S2 } & \multicolumn{2}{|l|}{ Pres-SI } \\
\hline & $M+C / C$ & $\begin{array}{l}\text { Cases with } \\
\text { membranous } \\
\text { pre-S2 }(\%)\end{array}$ & $M+C / C$ & $\begin{array}{l}\text { Cases with } \\
\text { membranous } \\
\text { pre-S1 }(\%)\end{array}$ \\
\hline $\begin{array}{l}\text { With active HBV replication } \\
\mathrm{HBeAg} \text { positive CAH }(n=8)\end{array}$ & $6 / 2$ & $75^{\star}$ & $4 / 4$ & $50 \dagger$ \\
\hline $\begin{array}{l}\text { Without active HBV replication } \\
\text { HBeAg positive CAH }(n=4) \\
\text { Anti-HBe positive CAH }(n=12) \\
\text { Subtotal }(n=16)\end{array}$ & $\begin{array}{l}0 / 4 \\
0 / 12 \\
0 / 16\end{array}$ & $\begin{array}{l}0 \\
0 \\
0^{\star}\end{array}$ & $\begin{array}{l}0 / 4 \\
0 / 12 \\
0 / 16\end{array}$ & $\begin{array}{l}0 \\
0 \\
0+\end{array}$ \\
\hline
\end{tabular}

For abbreviations, see Tables I and II.

${ }^{\star} \mathrm{p}<0.001,+\mathrm{p}<0.05$ (by $\chi^{2}$ test with Yates' correction). and cytoplasmic in 16, and exclusively cytoplasmic in 51. The expression of pre-S2 was solely membranous in one, mixed membranous and cytoplasmic in 32, and exclusively cytoplasmic in 35. Membranous expression of pre-S2 is significantly more frequent than that of pre-S1 $(48.5 \%$ or $33 / 68 v 25 \%$ or $17 / 68, \mathrm{p}<0.01)$.

Of 44 patients with chronic type $B$ hepatitis without hepatitis delta virus infection, 28 were positve for hepatitis $B$ virus-DNA in serum and $\mathrm{HBcAg}$ in the liver, and the remainder 16 were negative for both. The distribution of pre-S1 and pre-S2 in chronic type B hepatitis without hepatitis delta virus infection, in relation to the status of hepatitis B virus replication and histological activity, is listed in Table II. Diffuse membranous expression of pre-S2, usually in combination with focal cytoplasmic expression, was found in $27(96.4 \%)$ of 28 patients with active hepatitis B virus replication, irrespective of serum $\mathrm{HBeAg}$ or histological activity, but in none of 16 patients without active hepatitis $B$ virus replication $(p<0.001)$. Membranous expression of pre-S1 also correlated significantly with the status of hepatitis B virus replication. Cytoplasmic expression of pre-S1 and pre-S2 was noted in 43 and 43 patients, respectively. Semiquantitative analysis revealed that the degrees of cytoplasmic expression of pre-S1 as well as preS2 were significantly higher in patients without active hepatitis B virus replication than in those with (Table III).

Of the 24 patients with chronic type D hepatitis, eight were positive for hepatitis $B$ virusDNA in serum and HBcAg in the liver, and the remainder 16 were negative for both. Table IV shows the distribution of pre-S1 and pre-S2 in the liver in chronic hepatitis delta virus infection. Membranous expression of pre-S1 and preS2 correlated significantly with active hepatitis B virus replication. Moreover, a significantly higher degree of cytoplasmic expression of preS1 and pre-S2 was noted in patients without active hepatitis $B$ virus replication than in those with (Table V). The distribution and quantitative expression of pre-S1 and pre-S2 in the liver in patients with chronic type $\mathrm{D}$ hepatitis were comparable with those without hepatitis delta virus infection.

\section{Discussion}

The present results showed that all patients with chronic hepatitis B virus infection had pre-S1 or pre-S2 detectable in the liver, irrespective of the status of hepatitis B virus replication or histological activity. These findings are in keeping with the previous observations, ${ }^{12} 1315171920$ but are in contrast with the suggestion by other groups that the expression of pre-S1 or pre-S2 in liver varied with the status of hepatitis B virus replication. ${ }^{7+1618}$ This discrepancy may be because of the difference in the choice of antisera, tissue manipulation or staining protocols. Furthermore, the expression of $\mathrm{HBsAg}$ in liver was essentially identical to that of pre-S2 but not that of pre-S1, in keeping with the suggestion that transcription of mRNAs for $\mathrm{HBsAg}$ and pre-S2 is controlled by the same promotor, and that for pre-S1 is controlled independently by a second 
TABLE V Semiquantitative expression of pre-S1 and pre-S2 in hepatocyte cytoplasm in chronic type D hepatitis

\begin{tabular}{|c|c|c|c|c|c|c|c|c|c|c|}
\hline \multirow[b]{2}{*}{ Category } & \multicolumn{5}{|c|}{ Pre-S2 } & \multicolumn{5}{|c|}{ Pre-SI } \\
\hline & 0 & $1+$ & $2+$ & $3+$ & $4+$ & 0 & $1+$ & $2+$ & $3+$ & $4+$ \\
\hline $\begin{array}{l}\text { With active HBV replication } \\
\mathrm{HBeAg} \text { positive } \mathrm{CAH}(\mathrm{n}=8)\end{array}$ & 0 & 5 & 3 & 0 & $0^{\star}$ & 0 & 4 & 3 & 1 & $0 \dagger$ \\
\hline $\begin{array}{l}\text { Without active HBV replication } \\
\text { HBeAg positive CAH }(n=4) \\
\text { Anti-HBe positive CAH }(n=12) \\
\text { Subtotal }(n=16)\end{array}$ & $\begin{array}{l}0 \\
0 \\
0\end{array}$ & $\begin{array}{l}1 \\
1 \\
2\end{array}$ & $\begin{array}{l}1 \\
4 \\
5\end{array}$ & $\begin{array}{l}2 \\
4 \\
6\end{array}$ & $\begin{array}{l}0 \\
3 \\
3^{\star}\end{array}$ & $\begin{array}{l}0 \\
0 \\
0\end{array}$ & $\begin{array}{l}0 \\
0 \\
0\end{array}$ & $\begin{array}{l}2 \\
4 \\
6\end{array}$ & $\begin{array}{l}1 \\
5 \\
6\end{array}$ & $\begin{array}{l}1 \\
3 \\
4 \dagger\end{array}$ \\
\hline
\end{tabular}

For abbreviations, see Tables I and II. For scales of 0 to $4+$, see Table III

${ }^{\star} p<0.001,+p<0 \cdot 001$, and no significant difference $(p>0 \cdot 05)$ between pre-S2 and pre-S1 expression in each subgroup (by Wilcoxon's rank-sum test)

promotor. ${ }^{2122}$ This observation also implies that there is control at the level of translation of preS2 $v$ HBsAg.

Perhaps the more important finding of the present study is that the distribution and quantitative expression of pre-S1 and pre-S2 in the liver differed remarkably with the status of hepatitis B virus replication. During active replication of hepatitis B virus, nearly all patients had pre-S2 expression on the plasma membrane, regardless of serum $\mathrm{HBeAg}$ or liver inflammatory activity. Similarly, membranous expression of pre-S1 also correlated significantly with active hepatitis B virus replication (Table II). Previous studies by others have shown a close association between high levels of pre-S1 or pre-S2 in serum with hepatitis $\mathrm{B}$ virus-DNA in serum, ${ }^{47-12}$ in keeping with the observation that pre-S1 and pre-S2 are the essential components of complete virion. ${ }^{34}$ Taken together, it seems that, membranous expression of pre-S1 or pre-S2 in the liver is closely related to its presence in serum, and thus might reflect the secretion of the hepatitis $B$ virus particles containing pre-S peptides by liver into the circulation, suggesting a pathway through membranous system in assembly or secretion of hepatitis B virus particles. On the contrary, in patients without active hepatitis B virus replication, there is little or no membranous expression of pre-S1 or pre-S2, and, moreover, cytoplasmic expression of pre-S peptides increased remarkably compared with those with active hepatitis B virus replication (Table III). These findings might suggest that in the non-replicative phase of chronic hepatitis B virus infection, pre-S1 or preS2 is non-secretable, and thus will be retained within the cytoplasm of the hepatocytes. The reason for the relatively less prevalence of pre-S1 than of pre-S2 on the liver cell membrane during active hepatitis B virus replication, as shown in Table II, is not clear. A similar finding, however, has been reported recently by Suzuki et al..$^{20} \mathrm{It}$ remains possible that monoclonal antibody against pre-S1 used in the present study has less affinity to the plasma membrane of hepatocyte than that against pre-S2.

The mechanism responsible for secretion or intracellular retention of pre-S peptides in chronic hepatitis B virus infection is uncertain. Studies in cultured cells have suggested that the cosecretion or the inhibition of secretion of HBsAg/pre-S2 and pre-S1 might depend on their relative concentrations. ${ }^{23}{ }^{24}$ On the other hand, it has been suggested that, unlike $\mathrm{HBsAg}$, the pre$S$ peptides do not undergo the spontaneous budding process; rather the initiation of bud- ding might be triggered by interaction with the nucleocapsid or matrix components of the virus. $^{23+32}$ It seems more likely that, in the absence of active hepatitis $B$ virus replication and intracellular nucleocapsid protein $(\mathrm{HBcAg}$ ), surplus pre-S peptides can not migrate to the plasma membrane as part of new assembling particles and thus will accumulate in the cytoplasm.

Several studies have shown a close association between liver inflammatory activities and membrane associated pre-S1 or pre-S2 in chronic hepatitis $B$ virus infection, suggesting that membranous pre-S1 or pre-S2 might be a possible target antigen in T-cell mediated lysis of hepatocytes. ${ }^{1+16}$ Studies of the in vitro microcytotoxicity assays, however, have suggested hepatitis B virus capsid protein, rather than envelope protein, as a target viral antigen. ${ }^{33}$ The present results revealed that membranous expression of pre-S1 or pre-S2 was found in patients with hepatitis $B$ virus-DNA in serum or $\mathrm{HBcAg}$ in liver, regardless of the histological activity, suggesting that membranous expression of pre-Sl or pre-S2 is closely related to active replication of hepatitis B virus, rather than the extent of liver inflammatory activity.

With regard to the interference of pre-S1 or pre-S2 expression in the liver in chronic hepatitis delta virus infection, a recent study by Hadziyannis $e t a l^{3+}$ has suggested that intrahepatic expression of pre-S peptides in chronic hepatitis delta virus infection appeared to be independent of hepatitis $B$ virus and hepatitis delta virus replicative status. In the Hadziyannis's series, however, the vast majority of patients were negative for $\mathrm{HBeAg}$ in serum or $\mathrm{HBcAg}$ in the liver, and there was no quantitative data of pre-S peptide expression in the liver. The present results showed that the topographic distribution of pre-S1 and pre-S2 in the liver in HBsAg carriers with hepatitis delta virus infection correlated significantly with the status of hepatitis B virus replication (Table IV), and that, moreover, the distribution and quantitative expression of pre-S1 and pre-S2 were comparable with the hepatitis delta virus negative patients (Tables III, V). These findings suggested that in HBsAg carriers with chronic hepatitis delta virus infection the synthesis and expression of pre-S peptides in liver correlated closely with the underlying hepatitis $B$ virus replicative status and did not appear to be modulated by the concurrent hepatitis delta virus infection.

In conclusion, the present results suggested that all patients with chronic hepatitis $B$ virus infection had pre-S1 or pre-S2 display in the liver. The distribution and quantitative expression of pre-S peptides in the liver, however, were closely related to the status of hepatitis $B$ virus replication, but not to the histological activity. Concurrent hepatitis delta virus superinfection did not appear to modulate the synthesis and expression of pre-S peptides in the liver.

This study was supported by the National Science of Council of ROC (NSC80-0419-B-1282A-62). The authors thank Ms L F Yao for her secretarial assistance.

1 Tiollais P, Pourcel C, Dijean A. The hepatitis B virus. Nature 1985; 317: 489-95. 
2 Robinson WS, Klote L, Aoki N. Hepadnaviruses in cirrhotic liver and hepatocellular carcinoma. 7 Med Virol 1990; 31: 18-32.

3 Heermann KH, Goldmann U, Schwartz W, Seyffarth T Baumgarten $\mathrm{H}$, Gerlich WH. Large surface proteins of hepatitis B virus containing the pre-S sequence. $\mathcal{f}$ Virol 1984; 52: 396-402

4 Klinkert MQ, Theilmann L, Praff E. Pre-S1 antigens and antibodies early in the course of acute hepatitis $B$ virus infection. F Virol 1986; 58: 522-5.

5 Neurath AR, Jameson BA, Huima T. Hepatitis B virus proteins eliciting protective immunity. Microbiol Sci 1987; 4: 45-51.

6 Neurath AR, Kent SBH, Strick N. Identification and chemical synthesis of a host cell receptor binding site on hepatitis $B$ virus. Cell 1986; 46: 429-36.

7 Theilmann L, Klinkert MQ, Gmelin K, Salfeld J, Schallor H Pfaff E. Detection of pre-S1 proteins in serum and liver of HBsAg-positive patients: A new markers for hepatitis B HBsAg-positive patients: A new markers

8 Gerken G, Manns M, Gerlich WH. Pre-S encoded surface proteins in relation to the major surface antigens in acute hepatitis B virus infection. Gastroenterology 1987; 92: $1864-8$.

$9 \mathrm{Hu} \mathrm{KQ}$, Yu ZQ, Li FH, Hao LJ. Expression and clinical significance of pre-S1 and S2 proteins of $\mathrm{HBV}$ in sera of patients with chronic liver disease. Liver 1989; 9: 14652 .

10 Ibarra MZ, Mora I, Bartolome J, Porres JC, Carreno V. Detection of proteins encoded by the pre-S region of hepatitis B virus in sera of HBsAg carriers: relation to viral replication. Liver 1989; 9: 153-8.

11 Kurai K, Lino K, Koike K, Mitamura K, Endo Y, Oka H. Serum titers of pre-S(2) antigen in patients with acute and chronic type B hepatitis: relation to serum aminotransferase chronic type B hepatitis: relation to serum aminotransferase
activity and other hepatitis B virus markers. Hepatology activity and other

12 Hadziyannis S, Raimondo G, Papaioannou C, Anastassakos C Wong D, Sninsky J, et al. Expression of pre-S gene encoded proteins in liver and serum during chronic hepatitis $b$ virus infection in comparison to other markers of active viral replication. F Hepatol 1987; 5: 253-9.

13 Thung SN, Gerber MA, Kasamblides EJ, Gilja BA, Keh W, Gerlich WH. Demonstration of pre-S polypeptides of chronic hepatitis B virus carriers. Hepatology 1986; 6: 1315-8.

14 Hess G, Gerlich WH, Gerken G, Manns M, Meyer Zum Buschenfelde KH. Relationship of pre-S encoded antigens in liver and clinical manifestation of chronic hepatitis B in liver and clinical manifestation

15 Fraiese A, Pontisso P, Cavalletto D, Fattovich G, Alberti A. Expression of pre-S1 in liver of chronic hepatitis B virus carriers. F Hepatol 1988; 7: 157-63.

$16 \mathrm{Hu} \mathrm{KQ}$, Hao LJ, Zhang YY, Wang YK. Intrahepatic expression of pre-S proteins of hepatitis B virus and its possible relation to liver cell necrosis. Am $\mathcal{F}$ Gastroenterol 1989; 84: $1538-42$.

17 Saito T, Kamimura T, Asakura H, Ishikawa M. Ultrastructural localization of pre-S2 polypeptides in the liver tissues of patients with chronic hepatitis B virus infection. Liver 1989; 9: 329-37.

18 Dienes HP, Gerlich WH, Worsdorfer M, Gerken G, Bianchi $L$, Hess G, et al. Hepatic expression patterns of the large and middle hepatitis B virus surface proteins in viremic and nonviremic chronic hepatitis B. Gastroenterology 1990; 98: 1017-23.

19 Takaguchi K, Yamada G, Tsuji. Immunohistochemical study of pre-S(2) antigen in liver and serum of patients with chronic hepatitis B. Gastroenterol f pn 1990; 25: 343-9.

20 Suzuki K, Udrida T, Shikata T, Moiryama M, Arakawa Y Mizokami $M$, et al. Expression of pre-S1, pre-S2 and X peptides in relation to viral replication in livers with chronic hepatitis B. Liver 1990; 355: 364

21 Cattaneo R, Will H, Hernandez N, Schaller H. Signals regulating hepatitis $\mathrm{B}$ surface antigen transcription. Nature 1983; 305: 336-8.

22 Ou JH, Rutter WJ. Hybrid hepatitis B virus-host transcripts in a human hepatoma cell. Proc Natl Acad Sci USA 1985;82. 83-7.

23 Standring DN, Ou JH, Rutter WJ. Assembly of viral particles in Xenopus oocytes: pre-surface-antigens regulate secretion of the hepatitis B viral surface envelope particle. Proc Natl Acad SciUSA 1986; 83: 9338-42.

24 Persing DH, Vermus HE, Ganem D. Inhibition of secretion of hepatitis B surface antigen by a related presurface polypeptide. Science 1986; $234: 1388-91$.

25 Chu CM, Liaw YF. Intrahepatic distribution of hepatitis B surface and core antigens in chronic hepatitis $B$ virus infection. Hepatocyte with cytoplasmic/membranous hepatitis B core antigen as a possible target for immun hepatocytolysis. Gastroenterology 1987; 92: 220-5.

26 Rizzetto M, Canese MG, Gerin JL, London WT, Siy DL Purcell RH. Transmission of the hepatitis B virus-associated delta antigen to chimpanzee. $\mathcal{F}$ Infect Dis $1980 ; 141: 590$ 602 .

27 Hadziyannis SJ, Sherman M, Liberman HM, Shafritz DO. Liver disease activity and hepatitis B virus replication in chronic delta antigen-positive hepatitis B virus carriers. Hepatology 1985; 5: 544-7.

28 International Group. Acute and chronic hepatitis revisited. Lancet 1977; ii: 914-5.

29 Liaw YF, Pao CC, Chu CM, Sheen IS, Huang MJ. Changes of serum hepatitis $B$ virus DNA in two types of clinical events preceding spontaneous hepatitis $B$ e antigen seroconversio in chronic type B hepatitis. Hepatology 1987; 7: 1-3.

30 Chu CM, Liaw YF, Sheen IS, Chen TJ. Intrahepatic expression of $\mathrm{HBCAg}$ and delta antigen in anti-HBe positive HBsAg carriers with acute exacerbation or chronic liver disease. F Med Virol 1990; 30: 181-6.

31 Takai E, Machida A, Chnuma H, Miyamoto H, Tanaka T, Baba $\mathrm{K}$, et al. A solid-phase enzyme immunoassay for the determination of IgM and IgG antibodies against translation products of pre-S1 and pre-S2 regions of hepatitis B virus. products of pre-S1 and pre-S2 regio

32 Rodriguez-Boulan E, Sabatini DD. Asymmentric budding of viruses in epithelial monolayers: a model system for epithelial polarity. Proc Natl Acad Sci USA 1978; 75 5071-5.

33 Mondelli M, Mieli-Vergani G, Alberti A, Vergani G Portmann P, Eddleston LWF, et al. Specificity of T lymphocyte cytotoxicity to autologous hepatocytes in chronic hepatitis $B$ virus infection: evidence that $T$ cells are directed against HBV core antigen expressed on hepatocytes. F Immunol 1982; 129: 2773-8.

34 Hadziyannis SJ, Georgopoulou U, Psalidaki E, Budkowska A. Pre-S1 and pre-S2 gene encoded proteins in liver and serum in chronic hepatitis delta infection. 7 Med Virol 1991; 34: 14-9. 